\title{
ФОРМЫ И МЕТОДЫ КОЛОНИАЛЬНОЙ ПОЛИТИКИ ЦАРИЗМА В ГОДЫ КАВКАЗСКОЙ ВОЙНЫ 1763-1864 ГГ.
}

\section{FORMS AND METHODS OF TSARIST COLONIAL POLICY DURING THE CAUCASIAN WAR OF 1763-1864}

K. Unezhev

Summary: The article deals with some aspects of the Caucasian war of 1763-1864. Attention is mainly paid to the forms and methods of tsarist colonial policy during the Caucasian war. The novelty and relevance of the research lies in the fact that the forms and methods used by tsarism in the conquest of the Caucasus have not yet been specifically studied.

The article proves that tsarism conquered the Caucasus not only by military methods, but it used a variety of "peaceful" methods of conquering the region.

Keywords: The Caucasus; Circassian; to the mountaineers; war; Russia; politics; culture; economy.
Унежев Кашиф Хаждаутович

Д.ф.н., профессор, Кабадино-Балкарский государственный университет им. Х.М. Бербекова. г. Нальчик unegev_k@mail.ru

Аннотация: В статье рассматриваются некоторые аспекты Кавказской войны 1763-1864 гг. В основном уделяется внимание формам и методам колониальной политики царизма в годы Кавказской войны. Новизна и актуальность исследования заключается в том, что до сих пор конкретно не исследовались формы и методы, которые применялись царизмом при завоевании Кавказа. В статье доказано, что царизм завоевал Кавказ далеко не только военными методами, а он использовал самые разнообразные и «мирные» методы завоевания края.

Ключевые слова: Кавказ, черкесы, горцы, война, Россия, политика, культура, экономика.

Результатом этого является тот факт, что до настоящего времени нет единой методологии изучения этой важной проблемы исторической науки и подходы ученых ко многим ее аспектам расходятся, порой кардинально. Мы имеем в виду такие ее аспекты как: само название войны, ее хронологические рамки и характер, причины ее развязывания, итоги, степень участия некоторых горцев в ней и многое другое.

Несмотря на идеологический пресс, еще в 20-40 годы XX века академики И.Ю. Крачковский, М.Н. Покровский, профессора Б.В. Скитский, Р.М. Магомедов, С.К. Бушуев, А.В. Фадеев и другие отмечали, что Кавказская война со стороны России была колониальной и захватнической, а борьбу горцев Северного Кавказа - национально-освободительной. [1, с.3]

Еще К. Маркс и Ф. Энгельс не раз отмечали, что борьба горцев была борьбой за свою независимость, в которой участвовал сам народ. В частности, Ф. Энгельс в своей статье «Шансы войны» отмечал, что «настоящей войны, войны, в которой участвует сам народ мы не видели в центре Европы в течение нескольких поколений. Мы видели ее на Кавказе, в Алжире, где борьба продолжалась почти беспрерывно». [2, с.200]. А в другой его статье «Расцвет и упадок Армий» он же отмечал, что «Россия непрерывно вела войну на Кавказе». [3, с.94]. Он же в своем письме К. Марксу от 9 июня 1864 г. указывал, что за этими действиями «русских на Кавказе Европа взирает с идиотским равнодушием... Подавление польского восстания 
и овладение Кавказом - я считаю самыми серьезными событиями со времени 1815 года». [4, с.335].

Однако, в 1950 году в условиях административнодиктаторского метода исследований в исторической науке, эту борьбу горцев стали рассматривать не как антиколониальную, а ее участников как пособников империализма.

Одним из авторов такой антинаучной теории выступил М.К. Багиров. Он свои «идеи» изложил в статье «К вопросу о характере движения мюридизма Шамиля». В ней он характеризовал его как ставленника Турции и шпиона Англии. [5].

К сожалению, с таких же антинаучных позиций начали выступать с 80-х годов XX в. некоторые современные исследователи. [6]; [7]; [8]; [9].

Всем этим и другим работам по данной проблеме, на наш взгляд, дал объективную и убедительную оценку К.Ф. Дзамихов.[10, с.29-44].

В 1956г. в Москве и Махачкале проходили научные конференции, на которых была дана объективная оценка колониальной политике царизма, национально-освободительному движению горцев Северного Кавказа в годы Кавказской войны. В таком же русле проходили научные конференции в 80-90-е годы XX века почти во всех Северокавказских республиках, Ростове-на-Дону и других городах России, где были обсуждены многие аспекты проблемы Кавказской войны.

На этих форумах ученых-кавказоведов была дана принципиальная оценка колониальной политике царизма и, отмечено, что горцы Северного Кавказа в этой войне вели справедливую, национально-освободительную борьбу.

При завоевании Северного Кавказа, Россия использовала самые разнообразные формы и методы, некоторые из которых, на первый взгляд, не «вписывались» в классические методы колониальной политики других держав. Но основные формы и методы были такими же.

Данная статья посвящена одному аспекту этой войны- формам и методам, которые были использованы царизмом в своей колониальной политике в годы Кавказской воны.

Россия, задолго до начала Кавказской войны, стремилась закрепиться на Кавказе. Более интенсивное начало планомерного ее продвижения к югу, положил военнополитический союз, который был заключен в 1557 году, между Кабардой и Московским государством. Начиная с этого периода до XVIII века Россия имела с Кабардой военно-союзнические отношения, т.е. отношения носили мирный характер. Но с XVIII века Россия переходит к открытым военным методам освоения Северного Кавказа, т.е. к прямому военно-колонизационному покорению края. Просто она продолжила свою политику, которая проводилась с XVI века другими, а именно насильственными методами, т.е. военными.

В этом плане нельзя не вспомнить классическое определение К. Клаузевица, которое он дал войне: «Война в человеческом обществе, - писал он, - война целых народов, и, при том, народов цивилизованных, всегда вытекает из политического положения и вызывается лишь политическими мотивами. Она, таким образом, представляет собой политический акт ... Война есть не только политический акт, но и подлинное орудие политики, продолжение политических отношений, осуществление их другими средствами». [11, с. 9,10].

Таким образом, как было сказано выше, Россия несколько веков проводила политику освоения Северного Кавказа мирными методами, война, которую она развязала на Кавказе во второй половине XV111 в. просто являлась продолжением этой политики.

В этом с ней соперничали ни одно столетие Османская империя со своим вассалом Крымским ханством, Иран и позже западные страны.

Первой жертвой Российской империи в завоевании Кавказа стали адыги(черкесы). Это было не случайно и на это были свои веские причины, о чем будет указано ниже.

Еще в XVI веке Россия начинает предпринимать конкретные шаги по освоению Северного Кавказа. Для этой цели она удачно использует обращения некоторых кабардинских княжеских фамилий с просьбой построить на их территории военные крепости для защиты от турецких и татарских агрессий. В 1567г. Россия строит крепость в устье реки

Первые шаги Московского княжества в Сунжа, где она впадает в Терек и в 1588г. у устья того же Терека - Терский город. [12, с.18]укреплении его позиции на Кавказе наглядно прослеживаются в документах тех далеких времен, во взаимоотношениях между прорусски настроенной части кабардинского общества и Иваном Грозным. В частности, по поводу обращений кабардинцев к нему сказано, что 22 декабря 1566 г. «приехал ко царю и великому князю из Черкас Матлов - князь Темгрюкович, шурин царя и великого князя, а людей с ним 30 человек, бити челом государю царю и великому князю от отца своего Темгрюка - князя Айдаровича, чтобы государь пожаловал, для брежениа от недругов его велел город на реке Терке усть - Сююнчи реки поставити». [13, с.13]. И в 
феврале 1567 г. царь послал в Кабарду людей и велел им «на Тереке-реке Тегрюку - князю по его челобитью город поставити» [13, с.13]. Позже в 1585 г. царь Иван Грозный «велел им город поставить в Пятигорских черкасах на Терке-реке, на усть Сунцы-реки, и плотников бы пожаловал дал, кому город делати, и воеводу бы своего пожаловал послал с вогневым боем, который бы их оборонял от крымского царя и от иных недругов их» [13, с.47].

Таким образом, Иван Грозный очень умело и вовремя воспользовался обращением определенной части кабардинских феодалов к нему, чтобы он построил военную крепость на их территории. Прорусски настроенные кабардинцы получили в лице Ивана Грозного союзника в их борьбе не только с внешним врагом, но в борьбе и с внутренними его противниками. А для Московского княжества это обращение кабардинцев и постройка крепостей были хорошим поводом для дальнейшего проникновения России на Кавказ. С этого периода она практически начинает распространять свои порядки на Северном Кавказе. И это явилось одним из ранних методов ее колониальной политики на Северном Кавказе.

Фактически с этого периода Россия начала также планомерную колонизацию края, создавая населенные пункты казачества, русских и украинских крестьян.

В эти же годы Россия организовывает первые вооруженные столкновения с некоторыми кабардинскими княжескими фамилиями, которые выступали против Идаровых - первых ее союзников. Однако, широкомасштабные и регулярные карательные экспедиции она начала организовывать с конца XVIII века.

Россия в первую очередь пыталась утвердиться в Центральном Кавказе, поэтому она и начала войну с завоевания Кабарды, которая была, по признанию самого А.П. Ермолова, «многолюдная, коей жители, почитаемые храбрейшими между горцами, нередко по многолюдству своему отчаянно противостояли русским в кровопролитных сражениях». [14, с.283]

Кабарда была не только одной из многочисленных субэтносов адыгского (черкесского) мира, но она занимала один из самых главных стратегических районов в Центральном Кавказе и имела огромное влияние на соседние народы, многие из которых находились в вассальной зависимости от нее. Через нее проходила сухопутная дорога в Грузию. Эти и другие обстоятельства явились главной причиной начала завоевания Северного Кавказа Россией с Кабарды.

Другими словами, Россия не могла осуществить свои далеко идущие планы по ее выходу в районы Ближнего Востока, Центральной Азии, на Дарданеллы и Персидский залив, не овладев Кавказом. Она так же хорошо осознавала, что им невозможно овладеть обходным ходом с каспийского и черноморского флангов, пока Северный Кавказ не будет разрезан на две части в его центральном секторе. Именно здесь, в преддверии Дарьяльского ущелья, которое являлось кратчайшим путем сообщения с южным Кавказом, находилась Кабарда. [15, с.31]. Все эти обстоятельства послужили главной причиной, того что завоевание Кавказа начала Россия с адыгов и в первую очередь Кабарды.

С началом Кавказской войны, Россия начинает применять, помимо прежних форм и методов, которые использовались ею еще с шестнадцатого века, новые и самые разнообразные методы.

Теперь отметим основные методы и формы, которые применялись Россией в ходе Кавказской войны, которая продолжилась больше века.

B 60-е годы XVIII в. в крае появляется сплошная линия военных крепостей от Кизляра, заложенного еще в 1736 году, до Моздока, который был основан на территории Кабарды в 1763г. В 1777г начинается возведение 10 военных крепостей от Азова до Моздока, которая вошла в историю как «Кавказская линия» $[16$, с.20]. В нее входили такие крепости и укрепления, как Азов в устье Дона, крепость Донская (1777г.); Ставрополь (1777г.); Александров (1777г.); Георгиевск (1777г.); Моздок (1763г.). В эти же годы сооружаются на территории Кабарды такие крепости и укрепления как: Прохладная, Екатериноградская, Пятигорская, Солдатская, Кисловодская, Константиноградская и др. Эти крепости должны были отделить Кабарду от Чечни и других горцев.

А.П. Ермолов не только укрепил существующие военные крепости, но в 1822г под его руководством была основана новая цепь военных крепостей по территории Кабарды. Она получила название «Кабардинская линия», которая протянулась от так называемых Черных гор (от верховьев Кубани) до Владикавказа. В ее состав вошли такие крепости как: Каменомостская, Нальчикская, Баксанская, Черекская, Урухская, Чегемская, Урванская, Лескенская и несколько военных постов. [17, с.200-201].

В начале войны с черкесами Россия ограничивалась в основном передвижением вперед оборонительной линии, стесняя черкесов в пользовании пастбищами, а также время от времени совершая карательные экспедиции. Позже русские перешли к постепенному продвижению вглубь Черкесии, сопровождая его строительством дорог, прорубкой просек, с одновременным строительством на занимаемых землях казачьих станиц и русских поселений. При этом они клином врезались в адыгские земли, этим самым разобщая черкесов и их самих от других горцев. [18, с.356]. 
В частности, Россия переселяла из украинских и русских губерний государственных и крепостных крестьян, создавала казачьи станицы и деревни. Все эти мероприятия осуществлялись за счет земель горцев, в том числе Кабарды.

После заключения Кючук-Кайнарджийского мирного договора между Турцией и Россией в 1774 году, где Кабарда была объявлена составной частью России, она вводит на территорию Кабарды административносудебную систему управления, результатом которой явился установление военно-оккупационного режима в крае. В частности, в 1769г, она вводит в Кабарде институт приставства, в 1793г. создаются в той же Кабарде родовые суды и расправы, в 1785г. учреждается Кавказское наместничество с центром в Екатеринограде, в августе 1822г. был учрежден в Нальчике Временный кабардинский суд. Позже эти мероприятия были продолжены до $\mathrm{XX}$ в.

Россия в своей колониальной политике использовала и другие методы. В частности, она умело противопоставляла одни княжеские фамилии другим. Она так же, всячески поддерживала антикабардинские настроения, зависимых от нее народов (карачаевцы, балкарцы, осетины, чеченцы и ингуши). [19, с. 36.] Кроме этого она поддерживала антифеодальные выступления кабардинских крестьян, поощряя их бегство в русские крепости и вторичное принятие ими христианства.

Чтобы сделать горцев более «послушными» и лояльными к России, она вводит институт аманатства. В ходе войны, царская администрация всячески использовала всех горцев, которые относились к России лояльно. Она их принимала в свою армию, в милицию, создавала из них специальные отряды, которых потом использовали в борьбе против горцев.

Параллельно с этими мероприятиями она регулярно организовывала карательные экспедиции. Россия сознательно заносила в Кабарду эпидемии холеры, чумы и других болезней.

Даже сам Ермолов нагло отмечал: «Моровая язва была союзницею нашего против кабардинцев; ибо, уничтожив совершено все население Малой Кабарды и производя опустошение в Большой, до того их ослабила, что они не могли уже как прежде собираться в больших силах...». [20, с.283]

В ходе войны Кабарда была отрезана от соляных источников и это значительно повлияло на состояние одной из основных отраслей ее экономики - животноводство. В одной Кабарде к началу Кавказской войны было около двух миллионов овец и более семидесяти тысяч лошадей, не говоря уже о крупном рогатом скоте, и т.д.
Кабарда, которая занимала огромные территории в Центральном Кавказе, в ходе войны потеряла более 4/5 своей территории.

Россия в массовом порядке регулярно выжигала поля и вырубала виноградники и сады адыгов (черкесов).

Россия завоевывала горцев поэтапно. Она переселяла их из плодородных земель, где они проживали веками и загоняла в горы и болотистые края.

Ермолов ввел на территории Кабарды так называемую билетную систему, по которой запрещалось передвигаться горцам по своей территории без специального письменного разрешения. Кроме этого вводится институт доносительства, по которому горцы были обязаны доносить русской администрации о тех людях, которые передвигались по краю без специального письменного разрешения.

Значительно было ограничено ношение горцами оружия. Кроме этого были запрещены многие традиционные общественные институты как аталычество, куначество и т.д.

Россия создавала льготные условия торговли для тех, кто к ней относился лояльно, а для «непослушных» эти условия отменялись.

Россия освобождала крестьян от тех феодалов, которые сопротивлялись ей. Все это подрывало их мощь.

K 70-м годам XVIII века Кабарда была уже целиком окружена военными крепостями и отрезана от других горцев. В этих условиях она фактически приняла на себя первый удар России.

B конце XVIII начале X1X вB. с постройкой военной крепости Кисловодская и присоединением к России Грузии и постройкой Военно-грузинской дороги, завершается полная изоляция Кабарды. [21, с.37.].

Царские генералы, такие как Медем, Глазенап, Якоби, Булгаков, Ермолов, Засс и другие навсегда остались в памяти адыгов и других горцев Северного Кавказа, как самые жестокие военачальники. Один Булгаков в 1809 году, в результате своей карательной экспедиции сжег до основания 200 кабардинских сел. Были и другие примеры. Крупные сражения проходили на территории Кабарды в 1767, 1779, 1794, 1804, 1809, 1810 и других годах.

А.П. Ермолов, с его приходом на Северный Кавказ в 1816 году, продолжил практику карательных экспедиций своих предшественников, в частности в 1822, 1825 годах он организовал такие экспедиции против Кабар- 
ды, где было уничтожено много кабардинцев.

Кабарда к 1829 году теряет свою свободу, но продолжает борьбу вплоть до 40-х годов XIX века. Например, кабардинский владелец Магомед-Мырза Анзоров был старшим наибом Шамиля со своими воинами принимал участие в его движении. [22, с.9]

В ходе завоевания Кабарды, России приходилось идти на некоторые уступки ей. В частности, когда в национально-освободительном движении стало принимать самое активное участие духовенство в 1807 г., царизм учредил в Кабарде духовный суд Мехкеме. Верховный князь Кабарды одновременно стал председателем этого суда.

После потери Кабардой своей политической самостоятельности, в 1829 году центр сопротивления горцев переносится в Закубанье, Дагестан, Чечню.

Подобно Кючук-Кайнарджийскому договору 1774 года по Кабарде, Адрианопольский трактат, который был подписан между Россией и Турцией 02 (14 сентября) 1829 года, послужил основанием начала присоединения к России Северо-западного Кавказа и Черноморского побережья, т.е. западных адыгов (черкесов). С этого момента она начала проводить более активную политику в этом регионе и западные адыги стали в сфере противоречий этих держав и объектом агрессии России. [23, с.186-189]

Одним из действенных методов борьбы России с западными черкесами был метод их изоляции от внешнего мира. Она всячески воспрепятствовала военно-политическим контактам черкесов с иностранными государствами. Для этой цели она задействовала Черноморский флот. В 30-е годы XIX в. Россия открывает Черноморскую береговую линию и организовала полную блокаду Черноморского побережья Черкесии и Абхазии и они были лишены всякой помощи извне. [24, с. 143-155]

Западные адыги продолжили свою борьбу за независимость до окончания Кавказской войны 21 мая 1864 года. И здесь царские генералы, как Бескровный, Засс, Лазарев и другие действовали против западных адыгов такими же методами, что и в Кабарде вышеперечисленные русские генералы.

Адыги (черкесы) больше всех понесли ощутимые потери как в людских, территориальных, так и материальных ресурсах. Это был настоящий геноцид по отношению к ним. Чтобы не быть голословным, можно привести некоторые примеры. В одной Кабарде численность ее населения в годы Кавказской войны сократилась в 10 раз. В частности, из 350 тысяч кабардинцев в конце войны осталось только 35 тысяч. Они были либо уничтоже- ны, либо высланы в пределы Османской империи. Что касается таких крупных адыгских субэтносов, как шапсуги, абадзехи, бжедуги, натухаевцы, кемергоевцы и др., численность каждого из них, которая доходила до 500 тыс. и более человек, к концу войны осталось только по несколько десятков тысяч человек. А убыхи физически были уничтожены и их язык уже стал мертвым.

Таким образом, для адыгов (черкесов) Кавказская война была настоящим геноцидом. В настоящее время почти из 10 миллионов черкесов, более 90\% их населения разбросаны по всему миру и проживают в более чем в сорока странах мира и только около 5-7\% всех ныне живущих адыгов проживает на своей исторической Родине - Северном Кавказе.

По данным всероссийской переписи населения России 2010 года на территории РФ адыгов (черкесов) проживает чуть более 700 тысяч человек, в том числе в Республике Адыгея - свыше 120 тыс., в Кабардино-Балкарии около 517 тыс. кабардинцев, в Карачаево-Черкесии - свыше 73 тыс. черкесов (адыгов). [25, с.3]

Если известно, во сколько раз сократилась численность кабардинцев в годы Кавказской войны, то невозможно точно подсчитать число погибших и покинувших свою Родину среди западных адыгов. Сейчас потомки черкесов-мухаджиров компактно проживают в Турции, Иордании, Сирии, Германии и др. странах. В одной только Турции по неполным данным проживает до восьми миллионов черкесов, в Сирии около ста пятидесяти тысяч, в Иордании около семидесяти тысяч черкесов. Таков массовый Исход адыгов из своей Родины в результате Кавказской войны.

Победа в этой войне досталась самой России ценой огромных человеческих жизней и материальных затрат. В частности, она потеряла в ней более 77 тысяч солдат и офицеров. Только в 40-50-е годы XIX века на содержание кавказского корпуса и ведения войны Россия расходовала 10-15 миллионов ежегодно. [26, с.114].

Таким образом, Россия, задолго до начала Кавказской войны, начала постепенного и планомерного освоения Кавказа. Этому процессу ее продвижения на юг положил начало Иван Грозный еще с середины XV1 в., когда он заключил военно-политический союз с Кабардой в 1557 г.

В этом вопросе Россия умело использовала прорусски настроенные княжеские фамилии кабардинского общества, а позже и остальных горцев.

Вплоть до начала Кавказской воны она в основном использовала в своей кавказской политике мирные формы и методы. Но во второй половине XVIII века международная обстановка сложилась таким образом, что она 
начала завоевание края военными способами. При этом она использовали параллельно самые разнообразные и мирные формы и методы. Они касались почти все стороны жизни горцев.

РоссияначалазавоеваниеКавказа садыгов(черкесов). На то были свои веские причины. Во-первых, они занимали самые важные регионы Кавказа в военно-стратегическом отношении. Во-вторых, они имели огромное влияние на многие соседние с ними народы. В-третьих, они были самыми многочисленными и мощными по своей военно-экономической жизни.

Эта война прославила и победителей и, не в меньшей степени побежденных. Однако следует отметить, что колониальную политику царизма на Северном Кавказе, формы и методы его завоевания осуждали многие представители русской прогрессивной интеллигенции. К ним относятся декабристы Н.Н. Раевский, А. Розен, БестужевМарлинский, писатели А.С. Грибоедов, Н.А. Добролюбов, А.С. Пушкин, Л.Н. Толстой и др.

Не мало случаев было, когда русские солдаты переходили на сторону горцев или становились их кунаками. Сочувственно относились к ним простые русские крестьяне и казаки. Горцы сами по достоинству оценивали такие жесты доброй воли и доброжелательности. Храбро защищая свою землю, они не раз проявляли гуманизм к военнопленным.

Любая война рано или поздно заканчивается и наступает мир. Так получилось и после Кавказкой войны. Потомки тех, кто воевал тогда насмерть друг с другом, сейчас живут в одной большой стране - Российской Федерации. Каждая из сторон должна извлечь из этой страшной войны уроки. Сейчас и на Северном Кавказе живут и русские и горцы. Именно Россия, которая завоевала их, позже создала все условия для сохранения традиций, обычаев, языка горцев. В XX веке была создана для них, пусть во многом формальная, но своя национальная государственность, широкая сеть культурно-просветительских, научных учреждений и учебных заведений всех уровней. Были подготовлены национальные отряды интеллигенции. Осуществлены широкомасштабные мероприятия по созданию национальной промышленности и по подъему сельского хозяйства и многое другое. На все это нельзя закрывать глаза. К сожалению, следует констатировать тот факт, что такие условия не были созданы ни в одной стране, где проживают компактно черкесы за рубежом, которые составляют более $90 \%$ всех ныне живущих адыгов (черкесов).

Да, Россия завоевала горцев в ходе Кавказской войны, но она их не покорила. И, по меткому выражению Расула Гамзатова, действительно, «нас, горцев, не покорила Россия Ермолова, а пленила пушкинская поэзия». [26, с.114.] А она для горцев вечна.

Сейчас, когда мы живем в составе Российской Федерации, необходимо работать над тем, чтобы она процветала и крепла. Мы обречены жить в составе этой великой страны, и должны помнить это всегда. В деле возрождения адыгов (черкесов) и сохранения своей самобытности придется решить много проблем. Но это тема для специального исследования.

\section{ЛИТЕРАТУРА}

1. Кумыков Т.Х. Выселение адыгов в Турцию - последствие Кавказской войны. Нальчик - 1994. С.3.

2. Ф. Энгельс. Шансы войны. Маркс К. и Энгельс Ф. Сочинения. 2-е издание. Москва, 1960. Т.17. С 200.

3. Ф. Энгельс. Расцвет и упадок Армий. Маркс К. и Энгельс Ф. Сочинения. 2-е издание. Москва, 1960. Т. 17. С.94.

4. Ф. Энгельс. Письмо К. Марксу от 9 июня 1864г. Маркс К. и Энгельс. Сочинения. 2-е издание. Москва, 1863. Т. 30 С. 335.

5. Журнал: «Большевик», М., апрель, 1950.

6. Блиев М.М. «Кавказская война: социальные истоки, сущность». // История СССР. М.,1983, №3.

7. Он же. Россия и горцы Большого Кавказа. На пути к цивилизации. Москва, 2004.

8. Блиев М.М., Дегоев В.В. Кавказская война. М., 1994.

9. Виноградов В.Б., Айларова С.А. «К вопросу методологической несостоятельности некоторых терминов в оценке народно-освободительного движения горцев». // Народно-освободительное движение горцев Дагестана и Чечни в 20-50-х X1Х в. Всесоюзная научная конференция 20-22 июля 1989 г. Тезисы докладов и сообщений. Махачкала, 1989.

10. Дзамихов К.Ф. «Свое» и «чужое» прошлое, или Актуальные вопросы историографии Кавказской войны. // Метаморфоз vs Трасформация. Мультидисциплинарный подход к изучению истории адыгов в XIX-XXI Вв. Материалы Международной научной конференции 6 декабря 2013 г., Ростов-на-Дону, 2013. C.29-44.

11. Клаузевиц К. 0 войне. Подготовка текста и комментарий Н.А. Чалдымова. Москва, 1990.С.9,10.

12. И.Х. Тхамокова. Русское и украинское население Кабардино-Балкарии. Нальчик, «Эль - Фа», 2000. С. 18.

13. Кабардино-русские отношения в XV1-XV111вВ. в двух томах. (КР0) Москва, 1957. Т.1.С.13

14. Записки А.П. Ермолова 1798-1826. Москва, 1991. С.283. 
15. Р. Трахо. Черкесы. Нальчик, 1992. С.31.

16. И.Х. Тхамокова. Русское и украинское население Кабардино-Балкарии. Нальчик. «Эль - Фа», 2000. С.20.

17. К.Х. Унежев. История Кабарды и Балкарии. Нальчик. «Эль - Фа», 2005. С.200-201.

18. А. Фонвиль. Последний год войны Черкесии за независимость 1863-1864г. //Черкесы (Адыге) Нальчик, 1991. С.356.

19. Р. Трахо. Черкесы. Нальчик, 1992. С.36.

20. Записки А.П. Ермолова 1798-1826. Москва, 1991. С. 283.

21. Р. Трахо. Черкесы. Нальчик, 1992. С.37.

22. Т.Х. Кумыков. Выселение адыгов в Турцию - последствие Кавказской войны. Нальчик, 1994. С. 9.

23. А.Х. Бижев. Адыги Северо-Западного Кавказа и кризис восточного вопроса в конце 20-30-хгг. Х1Хв. Майкоп, 1994. С. 186-189.

24. А. Сохт. Черноморская береговая линия: Сущность и функции. //Россия и Черкесия (вторая половина XVIII в. - XIXв. Майкоп, 1995. С.143-155.

25. Черкесский вопрос: история, проблемы и пути решения. Нальчик, 000 «Тетраграф». 2012. С. 3.

26. К.Х. Унежев. Методология исследования некоторых аспектов проблемы Кавказской войны. // Метаморфоз vs Трасформация. Мультидсциплинарный подход к изучению истории адыгов в XIX-XXI вв. Ростов-на Дону. Издательство СКНЦ ВШ ЮФУ. 2013. С. 114.

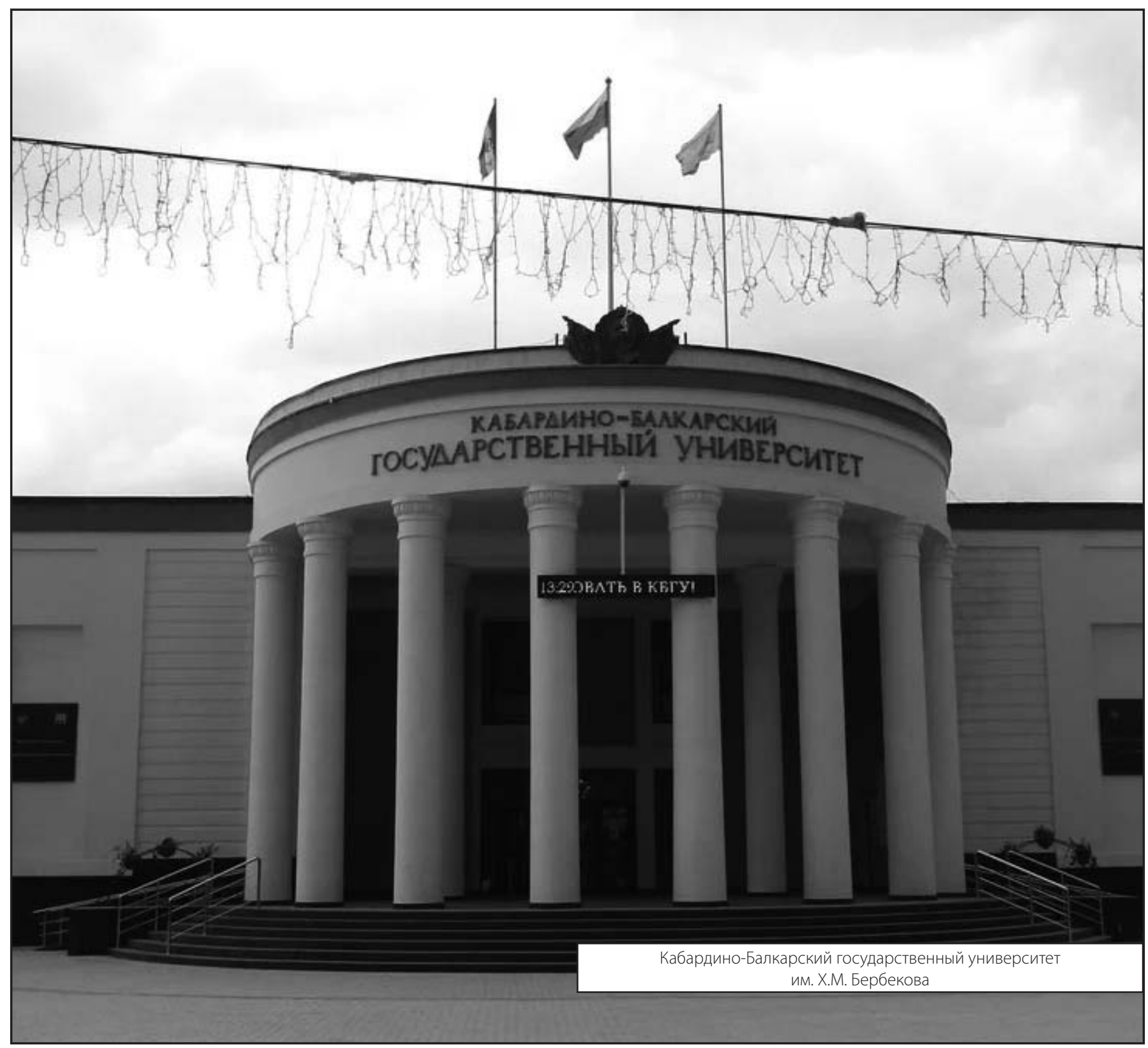

